\title{
Penggunaan Model Pembelajaran Creative Problem Solving (CPS) untuk Meningkatkan Kemampuan Pemecahan Masalah Matematis Siswa
}

\author{
Moch Gustiana Sulaeman $^{1}$, Nia Jusniani ${ }^{2 *}$, Erma Monariska ${ }^{3}$ \\ $1,2,3$ Universitas Suryakancana \\ ${ }^{*}$ niajusniani2010@gmail.com
}

\begin{abstract}
Abstrak
Tujuan dalam penelitian adalah untuk mengetahui apakah peningkatan kemampuan pemecahan masalah matematis siswa yang memperoleh model pembelajaran Creative Problem Solving (CPS) lebih baik dari pada kemampuan pemecahan masalah matematis siswa yang memperoleh pembelajaran biasa, serta untuk mengetahui sikap siswa terhadap model pembelajaran CPS yang digunakan adalah quasi eksperimen semu dengan desain Non Equivalent Group Pretest-Posttest Desaign. Populasi dalam penelitian ini adalah seluruh siswa kelas VIII SMP Negeri 2 Cilaku semester genap tahun 2017/2018. Adapun yang dijadikan sampel dalam penelitian ini adalah kelas VIII D sebagai keals eksperimen dan kelas VIII E sebagai kelas kontrol yang ditentukan menggunakan teknik Sampling Purposive. Untuk pengolahan data menggunakan instrumen tes kemampuan pemecahan masalah matematis siswa dan angket siswa. Berdasarkan hasil analisis data,dapat disimpulkan bahwa peningkatan kemampuan pemecahan masalah matematis siswa yang memperoleh model pembelajaran CPS lebih baik dari pada kemampuan pemecahan masalah matematis siswa yang memperoleh pembelajaran biasa dan sikap siswa terhadap model pembelajaran CPS adalah positif.
\end{abstract}

Kata kunci: Pemecahan masalah matematis siswa, Creative Problem Solving (CPS)

\begin{abstract}
The purpose of the study was to see whether the increase in the mathematical problem ability of students who obtained the Creative Problem Solving (CPS) learning model was better than the mathematical problem abilities of students who received ordinary learning, and to see students' attitudes towards the Creative Problem Solving (CPS) learning model. The method used is quasiexperimental with a Non-Equivalent Group Pretest-Posttest Design. The population in this study were all students of class VIII SMP Negeri 2 Cikalu even semester in 2017/2018. The samples in this study were class VIII D as a primary experiment and class VIII E as a control class which was determined using purposive sampling technique. For data processing using a test instrument of students' mathematical problem management abilities and student questionnaires. Based on the results of data analysis, it can show that the increase in the mathematical problem ability of students who get the Creative Problem Solving (CPS) learning model is better than the mathematical problem management abilities of students who get ordinary learning, and the students' attitudes towards the Creative Problem Solving (CPS) learning model are positive.
\end{abstract}

Keywords: students' mathematical problem solving, Creative Problem Solving (CPS)

\section{Pendahuluan}

Pendidikan adalah salah satu bidang yang berperan penting dalam mengembangkan kemampuan-kemampuan sumber daya manusia (SDM). Karena pendidikan merupakan upaya sadar dan terencana untuk mewujudkan suasana belajar dan proses pembelajaran agar peserta didik secara aktif mengembangkan potensi dirinya untuk memiliki kekuatan spiritual keagamaan, pengendalian diri, kepribadian, kecerdasan, akhlak mulia, serta 
keterampilan yang diperlukan dirinya, masyarakat, bangsa dan negara yang dinyatakan dalam pasal 1 Undang - Undang RI No. 20 tahun 2003 tentang Sistem Pendidikan Nasional (Syaripudin, 2006). Salah satu lembaga yang mengelola penyelenggaraan kegiatan pendidikan adalah sekolah. Sementara itu, inti dari penyelenggaraan pendidikan di sekolah, dilaksanakan dalam kegiatan pembelajaran.

Salah satu kegiatan pembelajaran yang dilaksanakan di sekolah adalah pembelajaran matematika. Tujuan dari pembelajaran matematika berdasarkan Peraturan Menteri Pendidikan Nasional Nomor 22, 23 dan 24 tahun 2006 adalah agar siswa memiliki kemampuan sebagai berikut:

a. Memahami konsep matematika, menjelaskan keterkaitan antar konsep dan mengaplikasikan konsep atau algoritma, secara luwes, akurat, efisien, dan tepat, dalam pemecahan masalah.

b. Menggunakan penalaran pada pola dan sifat, melakukan manipulasi matematika dalam membuat generalisasi, menyusun bukti, atau menjelaskan gagasan dan pernyataan matematika.

c. Memecahkan masalah yang meliputi kemampuan memahami masalah, merancang model matematika, menyelesaikan model dan menafsirkan solusi yang diperoleh.

d. Mengkomunikasikan gagasan dengan simbol, tabel, diagram, atau media lain untuk memperjelas keadaan atau masalah.

e. Memiliki sikap menghargai kegunaan matematika dalam kehidupan, yaitu memiliki rasa ingin tahu, perhatian, dan minat dalam mempelajari matematika, serta sikap ulet dan percaya diri dalam pemecahan masalah.

Berdasarkan uraian tersebut, salah satu kemampuan yang harus dimiliki siswa setelah mengikuti pembelajaran matematika adalah kemampuan dalam memecahkan masalah. Kemampuan-kemampuan lainnya yang harus dimiliki oleh siswa, ditujukan agar siswa dapat menggunakan kemampuan tersebut dalam memecahkan masalah. Sehingga dapat dikatakan bahwa fokus utama dalam pembelajaran matematika adalah mengembangkan kemampuan pemecahan masalah (Syaban, 2009).

Kemampuan pemecahan masalah merupakan salah satu bagian yang sangat penting dalam pembelajaran matematika sesuai dengan prinsip yang ada pada kurikulum 2013 bahwa pemecahan masalah merupakan bagian penting dari pembelajaran matematika dan kemampuan yang harus dicapai oleh siswa.Kemampuan pemecahan masalah juga digunakan pada kurikulum dari negara-negara lain (Jusra, 2013). Pemecahan masalah 
dapat memberikan keuntungan bagi siswa dalam belajar matematika (Purbawanto, 2013). Karena pemecahan masalah mendorong munculnya kreativitas, fleksibilitas, dan berpikir metakognitif yang sesuai dengan kebutuhan-kebutuhan profesional dan kebutuhan dalam kehidupan sehari-hari. Dengan kata lain, dengan belajar pemecahan masalah, siswa mempunyai kesempatan lebih banyak dalam menyiapkan diri untuk menghadapi berbagai aspek kehidupannya setelah menyelesaikan sekolah.

Berdasrkan hasil observasi pada beberpa orang guru, kemampuan pemecahan masalah matematis siswa masih rendah. Hasil dialog dengan pengajar matematika dan pengalaman mengajar di sekolah menunjukkan bahwa siswa masih merasa kesulitan dalam menyelesaikan soal-soal rutin apalagi dalam kemampuan pemecahan masalah matematisnya (Andriatna, 2012). Kondisi ini menguatkan hasil penelitian yang dilakukan oleh OECD PISA terhadap 7.355 siswa usia 15 tahun dari 290 SLTP/SMA/SMK seIndonesia tahun 2003 menunjukkan bahwa 7.070 siswa hanya mampu menguasai matematika sebatas satu masalah sederhana, mereka belum mampu menyelesaikan masalah kompleks dan rumit (Fitriani, 2010).

Penggunaan model pembelajaran menjadi salah satu faktor yang mempengaruhi proses pembelajaran. Dalam proses pembelajaran guru masih cenderung menggunakan metode konvensional (metode ceramah). Polapikir guru masih terlalu berfokus pada buku teks (text book thinking).

Berdasarkan masalah yang diungkapkan di atas, perlu adanya upaya untuk meningkatkan kemampuan pemecahan masalah matematis siswa. Salah satu hal yang dapat dilakukan untuk dapat meningkatkan kemampuan pemecahan masalah matematis siswa adalah dengan menggunakan pendekatan pembelajaran Creative Problem Solving (CPS).

Model pembelajaran Creative problem solving melatih siswa menyelesaikan suatu permasalahan dalam berbagai alternatif penyelesaian. Siswa mengerjakan permasalahan yang diberikan secara berkelompok, sehingga siswa dapat bertukar informasi mengenai pemahaman yang dimiliki setiap anggota kelompok. Dengan kemampuan yang beragam diharapkan siswa dapat menyelesaikan permasalahan yang diberikan. Langkah-langkah Creative Problem Solving meliputi penemuan fakta, penemuan masalah, penemuan gagasan, penemuan jawaban, dan penentuan penerimaan.

Berdasarkan uraian diatas, penulis menyimpulkan bahwa dengan penerapan model pembelajaran Creative Problem Solving (CPS) merupakan salah satu upaya untuk meningkatkan kemampuan pemecahan masalah matematis siswa. Oleh karena itu, tujuan 
dari penelitian ini adalah untuk mengetahui upakah peningkatan kemampuan pemecahan masalah matematis siswa yang memperoleh model pembelajaran Creative Problem Solving (CPS) lebih baik atau tidak daripada kemampuan pemecahan masalah matematis siswa yang memperoleh pembelajaran biasa, dan untuk mengetahui sikap siswa terhadap model pembelajaran Creative Problem Solving (CPS).

\section{Metode Penelitian}

Metode yang digunakan dalam penelitian ini adalah eksperimen kuasi atau eksperimen semu. Dikatakan demikian karena eksperimen jenis ini belum memenuhi persyaratan seperti cara eksperimen yang dapat dikatakan ilmiah mengikuti peraturanperaturan tertentu (Arikunto, 2006). Desain penelitian eksperimen kuasi yang digunakan dalam penelitian ini yaitu Nonequivalent Group pretest-postest Design yang digambarkan sebagai berikut :

\begin{tabular}{llll}
\hline Grup Eksperimen & $: \mathrm{O}_{1}$ & $\mathrm{X}$ & $\mathrm{O}_{2}$ \\
Grup Kontrol & $: \mathrm{O}_{3}$ & & $\mathrm{O}_{4}$
\end{tabular}

\section{Gambar 1. Rencana Nonequivalent Group Pretest-Postest Design} Keterangan :

$\mathrm{O}_{1} \quad$ : Pretest kemampuan pemecahan masalah matematis siswa kelas eksperimen

$\mathrm{O}_{2} \quad$ : Posttest kemampuan pemecahan masalah matematis siswa eksperimen

$\mathrm{O}_{3} \quad$ : Pretest kemampuan pemecahan masalah matematis siswa kontrol

$\mathrm{O}_{4} \quad$ : Posttest kemampuan pemecahan masalah matematis siswa kontrol

$\mathrm{X} \quad$ : Penerapan model pembelajaran Creative Problem Solving (CPS)

Lokasi penelitian bertempat di SMP Negeri 2 Cilaku. Populasi dalam penelitian ini adalah seluruh siswa kelas VIIISMP Negeri 2 Cilaku tahun pelajaran 2017/2018. Dari populasi tersebut diambil dua kelas sebagai sampel yaitu kelas VIII D sebagai kelas eksperimen dan kelas VIII E sebagai kelas kontrol yang ditentukan menggunakan teknik Sampling Purposive, yaitu teknik penentuan sampel dengan pertimbangan tertentu (Sugiyono, 2013). Kelas eksperimen diberikan perlakuan dengan menggunakan model pembelajaran Creative Problem Solving (CPS) sedangkan kelas kontrol diberikan 
perlakuan model pembelajaran yang biasa dilakukan guru saat mengajar. Berikut jumlah data sampel pada tabel 1 .

Tabel 1. Sampel PenelitianSiswa Kelas VIII SMP Negeri 2 Cilaku

\begin{tabular}{|c|c|c|c|c|}
\hline No & Kelas & Siswa Laki-laki & Siswa Perempuan & Jumlah \\
\hline 1 & VIII D & 19 & 17 & 36 \\
\hline 2 & VIII E & 19 & 17 & 36 \\
\hline \multicolumn{2}{|c|}{ Jumlah } & 38 & 34 & 72 \\
\hline
\end{tabular}

Penelitian ini menggunakan instrumen tes dan non tes. Instrumen tes dalam penelitian ini berbentuk uraianyaitu pretest untuk mengetahui sejauh mana kemampuan awal pemecahan masalah matematis siswa dan posttest untuk mengetahui kemampuan pemecahan masalah matematis siswasetelah mendapatkan perlakuan dengan pembelajaran Creative Problem Solving (CPS) pada kelas eksperimen maupun yang tidak mendapat perlakuan pada kelas kontrol, sedangkan untuk instrumen non tes berupa angket skala sikap siswa terhadap penggunaan model pembelajaran Creative Problem Solving (CPS) pada pembelajaran matematika. Instrumen non tes hanya akan diberikan kepada kelas eksperimen.

Instrumen tes terlebih dahulu diujicobakan untuk mengetahui validitas, reliabilitas, daya pembeda, dan indeks kesukarannya. Uji coba instrumen ini dilakukan pada siswa SMP Negeri 2 Cilaku kelas IX yang telah mempelajari materi pada tahun sebelumnya. Setelah uji coba instrumen tes selanjutnya dilakukan analisis data untuk mengetahui validitas, reliabilitas, daya pembeda, dan indeks kesukarannya.

Angket dalam penelitan ini bertujuan untuk mengetahui tentang sikap dan tanggapan siswa terhadap penerapan model pembelajaran Creative Problem Solving (CPS) dalam pembelajaran yang dilakukan oleh peneliti. Jenis angket dalam penelitian ini adalah angket check list $(\checkmark)$ dengan skala penilaian yang digunakan adalah skala Likert. Angket tersebut terdiri dari 26 pernyataan diantaranya 13 pernyataan yang bersifat postitif dan 13 pernyataan yang bersifat negatif. Setiap pernyataan dalam angket merupakan pernyataan tertutup sehingga siswa hanya memilih alternatif jawaban yang sesuai, yaitu : Sangat Setuju (SS), Setuju (S), Tidak Setuju (TS) dan Sangat Tidak Setuju (STS).

Data yang diperoleh dari penelitian ini berupa data kuantitatif dan data kualitatif. Data kuantitatif diperoleh dari hasil pretest dan posttest, sedangkan data kualitatif 
diperoleh dari hasil pengisian angket skala sikap siswa. Pengolahan data kuantitatif menggunakan software SPSS Versi.22 for windows, data input yang dianalisis adalah data hasil pretest, posttest,dan indeks gain yang akan diuji normalitas, uji homogenitas dan uji kesamaan dua rata-rata. Sedangkan untuk data kualitatif, mempresentasekan jumlah responden dari masing-masing pilihan jawaban. Untuk menentukan sikap siswa terhadap setiap pernyataan pada angket mengenai pembelajaran menggunakan model pembelajaran Creative Problem Solving (CPS)menggunakan modus, yaitu jumlah responden terbanyak pada setiap pernyataan.

\section{Hasil dan Pembahasan}

Setelah melaksanakan penelitian dan mendapatkan data yang diperlukan. Selanjutnya, dilakukan analisis mengenai data hasil pretest, posttest,indeks gain, dan angket skala sikap.

\section{a. Analisis Data Hasil Tes}

Analisis Data Pretest Kemampuan Pemecahan Masalah Matematis Siswa

Analisis data Pretest digunakan untuk mengetahui kemampuan awal pemecahan masalah matematis siswa antara kelas eksperimen dan kelas kontrol apakah sama atau tidak. Hasil deskripsi statistik data pretest kelas eksperimen dan kelas kontrol dapat dilihat pada tabel 2 .

Tabel 2. Deskripsi Statistik Skor PretestKelas Eksperimen dan Kelas Kontrol

\begin{tabular}{|l|c|c|c|c|c|}
\hline \multicolumn{1}{|c|}{ Kelas } & N & $\begin{array}{c}\text { Rata- } \\
\text { rata }\end{array}$ & Std. Deviation & $\begin{array}{c}\text { Skor } \\
\text { terendah }\end{array}$ & $\begin{array}{c}\text { Skor } \\
\text { tertinggi }\end{array}$ \\
\hline Pretest Eksperimen & 36 & 9,25 & 3,20 & 3 & 18 \\
\hline Pretest Kontrol & 36 & 9,89 & 5,35 & 3 & 21 \\
\hline
\end{tabular}

Berdasarkan Tabel 2, diperoleh rata-rata skor pretest kelas eksperimen adalah 9,25 dengan standar deviasi 3,20. Sedangkan untuk kelas kontrol diperoleh rata-rata 9,89dengan standar deviasi 5,35. Dari deskripsi data tersebut terlihat bahwa standar deviasi kelas kontrol lebih tinggi dari kelas eksperimen, artinya jawaban pretest kelas kontrol lebih beragam dibandingkan dengan kelas eksperimen, dan nilai rata-rata kelas kontrol lebih tinggi dari pada kelas eksperimen dengan selisih 0,64, selisih tersebut relatif kecil, namun untuk dapat menyimpulkan apakah kedua kelas tersebut memliki kemampuan awal yang 
sama secara signifikan atau tidak harus dilakukan uji statistik. Sebelum melakukan uji statistik tersebut, harus dilakukan uji prasyarat yakni uji normalitas distribusi populasi.

\section{Uji Normalitas Distribusi Populasi}

Uji normalitas ini dilakukan untuk mengetahui apakah data pretest yang akan di uji berdistribusi normal atau tidak. Untuk menghitung Normalitasnya, uji masing-masing kelompok sampel digunakan uji sampel Shapiro Wilk karena $\mathrm{N}<50$, dengan taraf signifikansi $(\alpha) 5 \%$. Perumusan hipotesis pengujian normalitas adalah sebagai berikut:

$\mathrm{H}_{0} \quad$ : Data Pretest berasal dari populasi berdistribusi normal

$\mathrm{H}_{1} \quad$ : Data Pretest berasal dari populasi yang berdistribusi tidak normal

Kriteria pengujian dalam penelitian ini adalah sebagai berikut :

$\mathrm{H}_{0}$ diterima, apabila nilai sig. (signifikansi) $\geq 0,05$.

$\mathrm{H}_{0}$ ditolak, apabila nilai sig. (signifikansi) $<0,05$.

Hasil uji normalitas dengan menggunakan uji Shapiro-Wilk dengan bantuan SPSS Versi 22 for Windows diperlihatkan pada tabel berikut :

Tabel 3. Hasil Uji Normalitas Skor Pretest Kelas Eksperimen dan Kelas Kontrol

\begin{tabular}{|l|c|}
\hline \multicolumn{1}{|c|}{ Kelas } & $\begin{array}{c}\text { Shapiro-Wilk } \\
\text { Sig. }\end{array}$ \\
\hline Pretest Eksperimen & 0,090 \\
\hline Pretest Kontrol & 0,011 \\
\hline
\end{tabular}

Berdasarkan tabel 3, hasil uji normalitas skor pretest kelas eksperimen dan kelas kontrol diperoleh nilai signifikasi berturut-turut adalah 0,090 dan 0,011. Karena nilai signifikansi dari salah satu kelas yaitu kelas kontrol kurang dari 0,05 maka $\mathrm{H}_{0}$ ditolak, artinya data skor pretest kelas kontrol tidak berdistribusi normal, maka selanjutnya dilakukan dengan uji non-parametrik dengan menggunakan uji Mann-Whitney.

\section{Uji Mann Whitney}

Berdasarkan hasil uji normalitas skor Pretest, menunjukkan bahwa sampel tidak berdistribusi normal, maka selanjutnya dilakukan uji non-parametrik Mann-Whitney untuk memperoleh kesimpulan apakah kemampuan pemecahan masalah matematis siswa kelas 
eksperimen dengan kelas kontrol sama atau tidak.Perumusan masalah hipotesis uji nonparametrik Mann-Whitney adalahsebagai berikut :

$\mathrm{H}_{0}: \mu_{1}=\mu_{2}$

$\mathrm{H}_{1}: \mu_{1} \neq \mu_{2}$

Dengan :

$\mu_{1}=$ Kemampuan awal pemecahan masalah matematis siswa kelas eksperimen

$\mu_{2}=$ Kemampuan awal pemecahan masalah matematis siswa kelas kontrol

Uji Mann-Whitney dilakukan dengan taraf signifikansi 0,05. Kriteria pengujiannya adalah sebagai berikut :

Jika nilai sig. $\geq 0,05$ maka $\mathrm{H}_{0}$ diterima

Jika nilai sig. $<0,05$ maka $\mathrm{H}_{0}$ ditolak

Hasil uji Mann-Whitney dengan menggunakanSoftwareSPSS Versi 22 for Windows diperlihatkan pada tabel berikut.

Tabel 4. Hasil Uji Mann Whitney Skor Pretest Kelas Eksperimen dan Kelas Kontrol

\begin{tabular}{|c|c|}
\hline & Nilai Pretest \\
\hline Mann-Whitney U & 646.000 \\
\hline Wilcoxon W & 1312.000 \\
\hline Z & -0.023 \\
\hline Asymp. Sig. (2-tailed) &, 982 \\
\hline
\end{tabular}

Berdasarkan tabel 4, hasil uji Mann Whitney skor pretest kelas eksperimen dan kelas kontrol diperoleh nilai Asymp. Sig. (2-tailed)sebesar 0,982 lebih besar dari 0,05 maka $\mathrm{H}_{0}$ diterima. Artinya, berdasarkan hasil analisis data pretes kedua kelas dapat disimpulkan bahwa kemampuan awal pemecahan masalah matematis siswa kelas eksperimen dan kelas kontrol sama.Karena diperoleh kemampuan awal kedua kelas sama, maka penelitian dapat dilanjutkan dengan memberikan perlakuan yang berbeda terhadap kedua kelas dengan tujuan untuk mengetahui peningkatan antara kedua kelas tersebut. 


\section{2) Analisis Data Posttest Kemampuan Pemecahan Masalah Matematis Siswa}

Data postest digunakan untuk mengetahui pencapaian kemampuan pemecahan masalah matematis siswa kelas eksperimen lebih baik atau tidak dari pada kelas kontrol. Pengolahan data ini menggunakan bantuan Software SPSS Versi 22 for Windows disajikan sebagai berikut.

Tabel 5. Statistik Deskriptif Posttest

\begin{tabular}{|l|c|c|c|c|c|}
\hline \multicolumn{1}{|c|}{ Kelas } & N & $\begin{array}{c}\text { Rata- } \\
\text { rata }\end{array}$ & Std. Deviation & $\begin{array}{c}\text { Skor } \\
\text { terendah }\end{array}$ & $\begin{array}{c}\text { Skor } \\
\text { tertinggi }\end{array}$ \\
\hline Posttest Eksperimen & 36 & 36,28 & 7,24 & 9 & 46 \\
\hline Posttest Kontrol & 36 & 36,47 & 4,09 & 20 & 39 \\
\hline
\end{tabular}

Berdasarkan Tabel. 5 di atas, rata-rata skor kelas eksperimen adalah 36,28 dengan Standar Deviation7,24, skor terendah 9, dan skor tertinggi 46. Sedangkan untuk rata-rata kelas kontrol adalah 36,47 dengan Standar Deviation 4,09, skor terendah 20, dan skor tertinggi 39. Secara deskriptif, perbedaan rata-rata skor posttest kedua kelas adalah 0,19. Untuk mengetahui apakah kemampuan pemecahan masalah matematis siswa sama atau berbeda secara sigifikan, maka dilakukan uji kesamaan dua rata-rata independen. Sebelum dilakukan uji kesamaan dua rata-rat independen data posttest, terlebih dahulu dilakukan uji normalitas apabila data berdistribusi normal dilanjutkan dengan uji homogenitas dan apabiladata tidak berdistribusi normal, maka selanjutnya dilakukan dengan uji nonparametrik dengan menggunakan uji Mann-Whitney.

\section{Uji Normalitas Distribusi Populasi}

Uji normalitas ini dilakukan untuk mengetahui apakah data posttest yang akan di uji berdistribusi normal atau tidak.Untuk menghitung Normalitasnya, uji masing-masing kelompok sampel digunakan uji sampel Shapiro Wilkkarena $\mathrm{N}<50$, dengan taraf signifikansi $(\alpha)$ 5\%. Perumusan hipotesis pengujian normalitas adalah sebagai berikut:

$\mathrm{H}_{0}$ : Data Posttest berasal dari populasi berdistribusi normal

$\mathrm{H}_{1}$ : Data Posttest berasal dari populasi yang berdistribusi tidak normal

Kriteria pengujian dalam penelitian ini adalah sebagai berikut :

$\mathrm{H}_{0}$ diterima, apabila nilai sig. (signifikansi) $\geq 0,05$.

$\mathrm{H}_{0}$ ditolak, apabila nilai sig. (signifikansi) $<0,05$. 
Hasil uji normalitas dengan menggunakan uji Shapiro-Wilk diperlihatkan pada tabel berikut:

Tabel 6. Hasil Uji Normalitas Skor Posttest

\begin{tabular}{|c|c|}
\hline \multirow{2}{*}{ Kelas } & Shapiro-Wilk \\
\cline { 2 - 2 } & Sig. \\
\hline Indeks Gain Eksperimen & 0,001 \\
\hline Indeks Gain Kontrol & 0,039 \\
\hline
\end{tabular}

Berdasarkan Tabel 6, diperoleh nilai signifikansi kelas eksperimen 0,001 dan signifikansi kelas kontrol 0,039. Nilai signifikansi kedua kelas menunjukkan kurang dari 0,05, maka menurut kriteria pengujian $\mathrm{H}_{0}$ ditolak. Sehingga dapat disimpulkan bahwa kedua kelas berasal dari populasi yang tidak normal, makaselanjutnya dilakukan dengan uji non-parametrik dengan uji Mann-Whitney.

\section{Uji Mann Whitney}

Berdasarkan hasil uji normalitas skor Posttest, menunjukan bahwa sempeltidak berdistribusi normal, maka selanjutnya dilakukan uji non-parametrik Mann-Whitney untuk memperoleh kesimpulan apakah kemampuan pemecahan masalah matematis siswa kelas eksperimen dengan kelas kontrol sama atau tidak.

Perumusan masalah hipotesis uji non-parametrik Mann-Whitney adalah sebagai berikut :

$\mathrm{H}_{0}: \mu_{1}=\mu_{2}$

$\mathrm{H}_{1}: \mu_{1} \neq \mu_{2}$

Dengan :

$\mu_{1}=$ Kemampuan awal pemecahan masalah matematis siswa kelas eksperimen

$\mu_{2}=$ Kemampuan awal pemecahan masalah matematis siswa kelas kontrol

Uji Mann-Whitney dilakukan dengan taraf signifikansi 0,05. Kriteria pengujiannya adalah sebagai berikut :

Jika nilai sig. $\geq 0,05$ maka $\mathrm{H}_{0}$ diterima

Jika nila sig. $<0,05$ maka $\mathrm{H}_{0}$ ditolak

Hasil uji Mann-Whitney dengan menggunakan Software SPSS Versi 22 for Windows diperlihatkan pada tabel berikut. 
Tabel 7. Hasil Uji Mann-Whitney (Postsest)

\begin{tabular}{|c|c|}
\hline & Indeks Gain \\
\hline Mann-Whitney U & 345.500 \\
\hline Wilcoxon W & 1011.500 \\
\hline Z & -3.416 \\
\hline Asymp. Sig. (2-tailed) & .001 \\
\hline
\end{tabular}

Berdasarkan tabel 7, diperoleh hasil uji Mann-Whitney dengan Asymp Sig -(2tailed) sebesar 0,001. Karena 0,001 kurang dari 0,05, maka $\mathrm{H}_{0}$ ditolak. Berdasarkankriteria pengujian sebelumnya, maka dapat disimpulkan pencapaian kemampuan pemecahan masalah matematis siswa yang memperoleh model pembelajaran Creative Problem Solving (CPS) lebih baik daripada kemampuanpemecahan masalah matematis siswa yang memperoleh pembelajaran biasa.

\section{Analisis Data Indeks Gain}

Pengolahan data indeks gain bertujuan untuk mengetahui apakah peningkatan kemampuan pemecahan masalah matematis siswa kelas eksperimen lebih tinggi daripada kelas kontrol. Pengolahan data ini menggunakan bantuan SoftwareSPSS Versi 22 for Windows sebagai berikut:

Tebel 8. Deskripsi Statistik Indeks Gain Tes Kemampuan Pemecahan Masalah Matematis Siswa Kelas Eksperimen dan Kelas Kontrol

\begin{tabular}{|l|c|c|c|c|c|}
\hline \multicolumn{1}{|c|}{ Kelas } & $\mathbf{N}$ & $\begin{array}{c}\text { Rata- } \\
\text { rata }\end{array}$ & Std. Deviation & $\begin{array}{c}\text { Skor } \\
\text { terendah }\end{array}$ & $\begin{array}{c}\text { Skor } \\
\text { tertinggi }\end{array}$ \\
\hline Indeks GainEksperimen & 36 & 0,67 & 0,17 & 0,05 & 0,90 \\
\hline Indeks GainKontrol & 36 & 0,56 & 0,09 & 0,25 & 0,74 \\
\hline
\end{tabular}

Berdasarkan Tabel 8, diperoleh bahwa rata-rata indeks gain kelas eksperimen sebesar 0,67 dengan Standar Deviation 0,17 sedangkan rata-rata indeks gain kelas kontrol sebesar 0,56 dengan Standar Deviation0,09. Data tersebut menunjukan bahwa rata-rata antara kelas eksperimen dan kelas kontrol berbeda. Untuk pengujian secara statistik, maka akan dilakukan uji normalitas terlebih dahulu antara kelas eksperimen dan kelas kontrol. 


\section{Uji Normalitas Distribusi Populasi}

Uji normalitas ini dilakukan untuk mengetahui apakah data indeks gain berasal dari populasi berdistribusi normal atau tidak. Untuk menghitung Normalitasnya, uji masingmasing kelompok sampel digunakan uji sampel Shapiro Wilk karena $\mathrm{N}<50$, dengan taraf signifikansi ( $\alpha$ ) 5\%. Perumusan hipotesis pengujian normalitas adalah sebagai berikut:

$\mathrm{H}_{0}$ : Data indeks gain berasal dari populasi berdistribusi normal

$\mathrm{H}_{1}$ : Data indeks gain berasal dari populasi yang berdistribusi tidak normal

Kriteria pengujian dalam penelitian ini adalah sebagai berikut :

$\mathrm{H}_{0}$ diterima, apabila nilai sig. (signifikansi) $\geq 0,05$.

$\mathrm{H}_{0}$ ditolak, apabila nilai sig. (signifikansi) $<0,05$.

Hasil uji normalitas dengan menggunakan uji Shapiro-Wilk diperlihatkan pada tabel berikut :

\section{Tabel 9. Hasil Uji Normalitas Indeks GainKelas Eksperimen dan Kelas Kontrol}

\begin{tabular}{|c|c|}
\hline \multirow{2}{*}{ Kelas } & Shapiro-Wilk \\
\cline { 2 - 2 } & Sig. \\
\hline Indeks Gain Eksperimen & 0,001 \\
\hline Indeks Gain Kontrol & 0,046 \\
\hline
\end{tabular}

Berdasarkan Tabel 9, diperoleh nilai signifikansi kelas eksperimen sebesar 0,001 dan signifikansi kelas kontrol sebesar 0,046. Nilai signifikansi kedua kelas menunjukkan kurang dari 0,05, maka menurut kriteria pengujian $\mathrm{H}_{0}$ ditolak. Sehingga dapat disimpulkan bahwa kedua kelas berasal dari populasi yang tidak normal, maka selanjutnya dilakukan dengan uji non-parametrik dengan menggunakan uji Mann-Whitney.

\section{Uji Mann Whitney}

Uji dilakukan untuk memperoleh kesimpulan apakah kemampuan pemecahan masalah matematis siswa yang memperoleh model pembelajaran Creative Problem Solving (CPS) lebih baik atau tidak dari pada kemampuan pemecahan masalah matematis siswa yang memperoleh pembelajaran biasa. Perumusan hipotesis pengujian dua rata-rata uji Mann-Whitney adalah sebagai berikut: 
$\mathrm{H}_{0}: \mu_{1}=\mu_{2}$

$\mathrm{H}_{1}: \mu_{1} \neq \mu_{2}$

Dengan :

$\mu_{l}=$ Peningkatan kemampuan pemecahan masalah matematis siswa kelas eksperimen

$\mu_{2}=$ Peningkatan kemampuan pemecahan masalah matematis siswa kelas kontrol

Uji Mann-Whitney dilakukan dengan taraf signifikansi 0,05. Karena dalam pengujian ini menggunakan uji satu pihak (1-tailed), maka nilai signinifikansi (2tailed) harus dibagi dua. Kriteria pengujiannya adalah sebagai berikut :

Jika $1 / 2$ nilai sig. $\geq 0,05$ maka $\mathrm{H}_{0}$ diterima

Jika $1 / 2$ nila sig. $<0,05$ maka $\mathrm{H}_{0}$ ditolak

Hasil uji Mann-Whitney dengan menggunakan SoftwareSPSS Versi 22 for Windows diperlihatkan pada tabel berikut.

Tabel 10. Hasil Uji Mann Whitney Indeks GainKelas Eksperimen dan Kelas Kontrol

\begin{tabular}{|c|c|}
\hline & Indeks Gain \\
\hline Mann-Whitney U & 303.500 \\
\hline Wilcoxon W & 969.500 \\
\hline Z & -3.882 \\
\hline Asymp. Sig. (2-tailed) &, 000 \\
\hline
\end{tabular}

Berdasarkan Tabel 10, dapat dilihat bahwa nilai Signifikansi (2-tailed) sebesar 0,000. Dikarenakan pengujian menggunakan uji satu pihak maka (1-tailed), maka nilai signinifikansi (2-tailed) harus dibagi dua sehingga nilai signifikansi 1-tailed adalah 0,000. Nilai tersebut lebih kecil dari 0,05. Maka $\mathrm{H}_{0}$ ditolak, berarti dapat disimpulkan bahwa kemampuan pemecahan masalah matematis siswa yang memperoleh model pembelajaran Creative Problem Solving (CPS) lebih baik dari pada kemampuan pemecahan masalah matematis siswa yang memperoleh pembelajaran biasa. 


\section{b. Analisis Data Angket}

Indikator dari angket skala sikap siswa ini adalah menunjukan sikap terhadap pembelajaran matematika dengan model pembelajaran Creative Problem Solving (CPS). Berikut ini disajikan rekapitulasi hasil angket sikap siswa.

\section{Tabel 11. Persentase Total Sikap Siswa Terhadap Model Pembelajaran Creative} Problem Solving (CPS)

\begin{tabular}{|c|c|c|}
\hline Sikap Positif & Sikap Negatif & Keterangan \\
\hline $79 \%$ & $21 \%$ & Pada Umumnya Positif \\
\hline
\end{tabular}

Berdasarkan tabel 11, diperoleh modus presentase sikap siswa sebesar 79\% yaitu pada sikap positif, maka dapat disimpulkan bahwa pada umumnyasiswa menunjukkan sikap yang positif terhadap penggunaan model pembelajaran Creative Problem Solving (CPS)saat pembelajaran matematika berlangsung. Hal tersebut terlihat pada saat proses pembelajaran berlangsung dengan menggunakan model pembelajaran Creative Problem Solving (CPS)sikap siswa sangat baik, terlihat dari keaktifan siswa dan kinerja siswa dalam diskusi kelompok, serta terlihat dari keberagaman jawaban yang masing-masing kelompok dapatkan dari hasil diskusi tersebut.

\section{Simpulan}

Berdasarkan hasil analisis dan pembahasan, diperoleh beberapa kesimpulan berkaitan dengan model pembelajaran Creative Problem Solving (CPS) terhadap kemampuan pemecahan masalah matematis siswa, dapat disimpulkan sebagai berikut :

1) Peningkatan kemampuan pemecahan masalah matematis siswa yang memperoleh model pembelajaran Creative Problem Solving (CPS) lebih baik daripada kemampuan pemecahan masalah matematis siswa yang memperoleh pembelajaran biasa.

2) Pada umumnya sikap siswa terhadap model pembelajaran Creative Problem Solving (CPS)adalah positif.

Berdasarkan hasil penelitian dan kesimpulan yang diperoleh mengenai pembelajaran dengan menggunakan model pembelajaran Creative Problem Solving (CPS)terhadap kemampuan pemecahan masalah matematis siswa, maka saran-saran yang dapat disampaikan sebagai berikut : 
1) Guru dapat menerapkan model pembelajaran Creative Problem Solving (CPS) sebagai salah satu upaya untuk meningkatkan kemampuan pemecahan masalah matematis siswa.

2) Guru matematika yang hendak menggunakan model pembelajaran Creative Problem Solving (CPS) ini, hendaknya melakukan persiapan yang lebih optimal terutama dalam pengaturan waktu,karena dalam CPS ini waktu yang dibutuhkan relatif lebih lama dari pada pembelajaran biasa.

3) Untuk peneliti selanjutnya, diharapkan dapat mengembangkan kegiatan penelitian dengan model pembelajaran Creative Problem Solving (CPS) lebih baik lagi dalam pembelajaran terhadap kemampuan pemecahan masalah matematis siswa.

\section{Referensi}

Andriatna, R. (2012). Meningkatkan Kemampuan Pemecahan Masalah Matematis Siswa SMA Melalui Menulis Matematika Dalam Pembelajaran Bebasis Masalah. Skripsi Jurusan Pendidikan Matematika FPMIPA UPI Bandung: Tidak Diterbitkan.

Arikunto, S. 2006. Prosedur Penelitian Suatu Pendekatan Praktik, Edisi Revisi VI. Jakarta: Rineka Cipta.

Depdiknas. (2006). Peraturan Menteri Pendidikan Nasional Nomor 22, 23 dan 24 tahun 2006 tentang Standar Isi untuk Satuan Pendidikan Dasar Dan Menengah. Jakarta : Depdiknas.

Fitriani, N. (2010). Pengaruh Penggunaan Model Pembelajaran Kooperatif Tipe Two Stay Two terhadap Kemampuan Pemecahan Masalah Matematika Siswa. Skripsi Jurusan Pendidikan Matematika FPMIPA UPI Bandung: Tidak Diterbitkan.

Jursa, H. (2013). Peningkatan Kemampuan Pemecahan Masalah Matematis Dan Kemandirian Belajar Siswa Kelas VII SMPMelalui Pendekatan Metacognitive Nter Speech. Desertasi SPS UPI. Bandung: Tidak Diterbitkan.

Purbawanto, S.. (2013). Peningkatan Kemampuan Pemecahan Masalah, Komunikasi Dan Self-Efficacy Matematis Mahasiswa Melalui Pembelajaran Dengan Metacognitive Scaffolding. Desertasi SPS UPI. Bandung: Tidak Diterbitkan.

Sugiyono. (2013). Metode Penelitian Kuantitatif, Kualitatif dan R\&D. Bandung: Alfabeta.CV

Syaban, M. (2009). Menumbuhkan Daya Matematis Siswa. [Online]. Tersedia: http://educare.e-fkipunla.net[10 Januari 2018].

Syaripudin, T. (2006). Landasan Pendidikan. Bandung: FIP UPI. 